\title{
Interaction of Piles and Raft
}

\author{
Tõnis Kull ${ }^{1}$, Mait Mets², Villu Leppik ${ }^{3}$ \\ Institute of Forestry and Rural Engineering, Department of Rural Engineering, \\ Estonian University of Life Sciences, Tartu, Estonia \\ E-mails: 'tonis@antaares.ee; ${ }^{2}$ mait.mets@gmail.com (correspondingauthor); ${ }^{3}$ villu.leppik@emu.ee
}

\begin{abstract}
The current article analyses model tests carried out at the laboratory of the Estonian University of Life Sciences. The behaviour or piles in soil was tested both with and without the raft. The tests showed that the raft influences the behaviour and bearing capacity of the pile foundations.
\end{abstract}

Keywords: side friction, load bearing capacity, bearing capacity of raft, self-regulating system, changes in pile load bearing capacity with different rafts.

Conference topic: Design experiences and theoretical solutions.

\section{Introduction}

Using of pile and raft interaction enables more rational solutions today and in the future. Piles in this selfregulating system are loaded over the limit load and the bearing capacity requirement is assured with the interaction of rafts and piles. This phenomen is investigated in named work (Kull 2014).

\section{Test methods}

The piles were steel pipes that were $620 \mathrm{~mm}$ long and $33 \mathrm{~mm}$ in diameter. The piles were rigidly attached to the raft plate with bolts. The raft was a metal plate $400 \times 400 \times 20 \mathrm{~mm}$ in size. The measurements of the testing sandbox were $3500 \times 2000 \times 2000 \mathrm{~mm}$. The test place is shown on Figure 1.

The tests were carried out in fine sand the composition of which can be seen on Figure 2.

Up to 80 percent of the sand was composed of fractions $0.15-0.5 \mathrm{~mm}$ in size. The dry density of the sand was $14 \mathrm{kN} / \mathrm{m}^{3}$, water content $\mathrm{w}=4 \%$, density $\mathrm{I}_{\mathrm{d}}=0.45$ and the angle of shearing resistance 35 degrees.

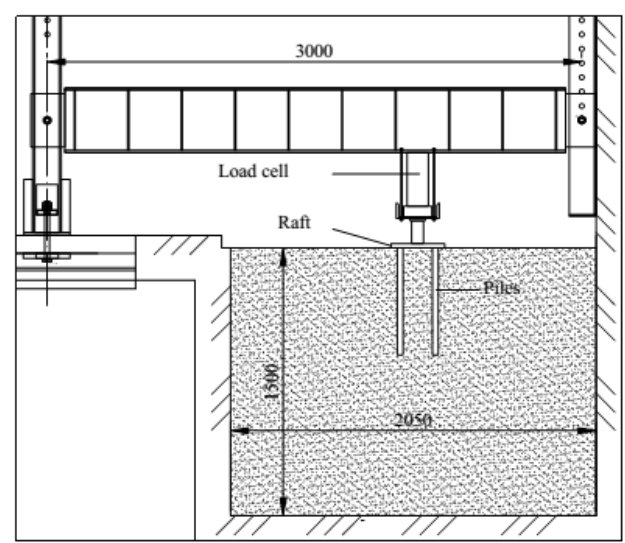

Fig. 1. View of test place

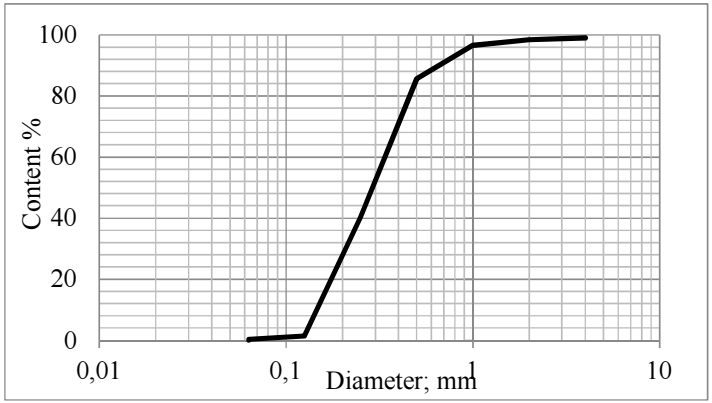

Fig. 2. Particle size distribution curve

The first tests were done with a high raft that did not impact the behaviour of piles. Pile groups of 1, 3, 4, 5 and 9 piles were tested. During the tests the side friction, creep point and the ultimate load of the piles were determined and the differentials under the pile end and side were calculated. The diagrams of tests are shown on Figure 3 and in Table 1.
3.
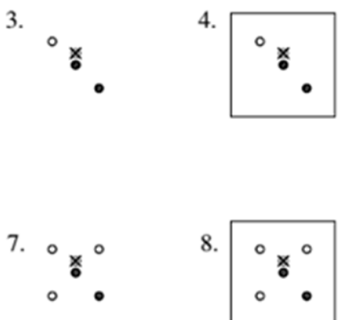

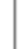

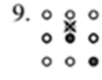

1.

×
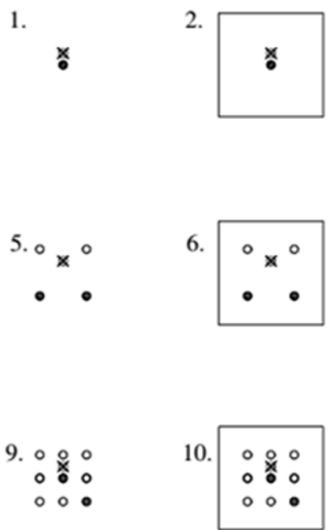
\section{(n)}

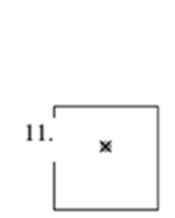

Fig. 3. Foundation models and tests series according to the method used: $\mathbb{X}_{\mathrm{N}}$-plate pressure sensor; - pile with pressure sensor; $\bigcirc$ - pile; $\square$ - pile raft 
Table 1. Specification of models

\begin{tabular}{c|c|c|c|c}
\hline $\begin{array}{c}\text { Test } \\
\text { se- } \\
\text { quen- } \\
\text { ce }\end{array}$ & Model & $\begin{array}{c}\text { Number } \\
\text { of piles }\end{array}$ & $\begin{array}{c}\text { Gap dis- } \\
\text { tance } \\
\text { between } \\
\text { piles, mm }\end{array}$ & $\begin{array}{c}\mathrm{d} / \mathrm{D} \text { gap } \\
\text { distance/ } \\
\text { pile dia- } \\
\text { metre }\end{array}$ \\
\hline 1 & Single pile & 1 & - & - \\
\hline 2 & Plate +1 pile & 1 & - & - \\
\hline 3 & 3 piles & 3 & 125 & 3.8 \\
\hline 4 & Plate +3 piles & 3 & 125 & 3.8 \\
\hline 5 & 4 piles & 4 & 180 & 5.5 \\
\hline 6 & Plate +4 piles & 4 & 180 & 5.5 \\
\hline 7 & 5 piles & 5 & $125 ; 180$ & $4 ; 5.5$ \\
\hline 8 & Plate +5 piles & 5 & $125 ; 180$ & $4 ; 5.5$ \\
\hline 9 & 9 piles & 9 & 90 & 2.7 \\
\hline 10 & Plate +9 piles & 9 & 90 & 2.7 \\
\hline 11 & Plate & - & - & - \\
\hline
\end{tabular}

\section{Test results}

The results of pile tests are shown on Figure 4 and Table 2 .

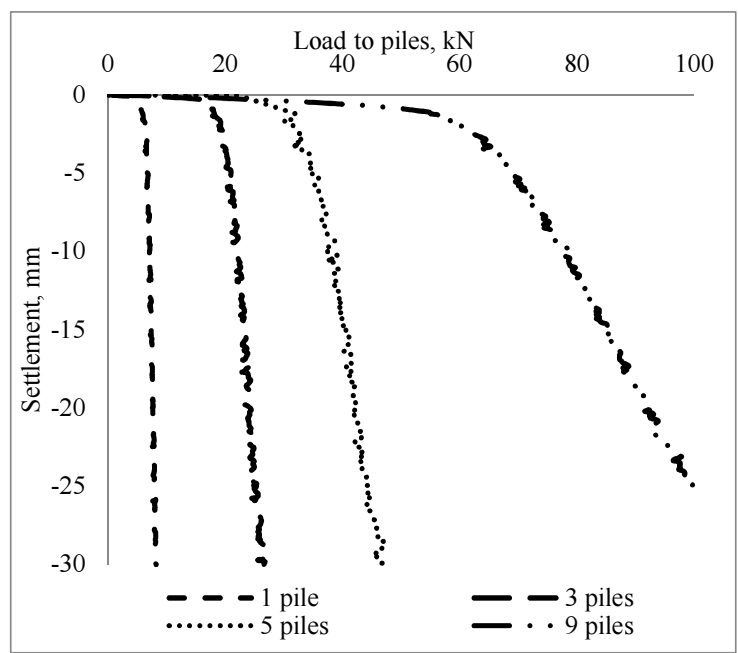

Fig. 4. Load and settlement curve of piles

Table 2. Test results of piles

\begin{tabular}{c|c|c|c|c|c|c}
\hline $\begin{array}{c}\text { Number of } \\
\text { piles }\end{array}$ & $\begin{array}{c}\mathrm{N}_{\mathrm{a}} \\
\mathrm{kN}\end{array}$ & $\begin{array}{c}\mathrm{N}_{\mathrm{y}} \\
\mathrm{kN}\end{array}$ & $\begin{array}{c}\mathrm{N}_{\mathrm{f}} \\
\mathrm{kN}\end{array}$ & $\begin{array}{c}\tau_{\mathrm{a}} \\
\mathrm{kN} / \mathrm{m}^{2}\end{array}$ & $\begin{array}{c}\sigma_{\mathrm{y}} \\
\mathrm{kN} / \mathrm{m}^{2}\end{array}$ & $\begin{array}{c}\sigma_{\mathrm{t}} \\
\mathrm{kN} / \mathrm{m}^{2}\end{array}$ \\
\hline 1 & 3 & 6 & 8 & 50 & 3000 & 5000 \\
\hline 3 & 8 & 17 & 23 & 50 & 3000 & 5000 \\
\hline 4 & 14 & 28 & 42 & 58 & 3500 & 7000 \\
\hline 5 & 15 & 30 & 46 & 50 & 3000 & 6200 \\
\hline 9 & 30 & 60 & 100 & 55 & 3300 & 7700 \\
\hline
\end{tabular}

Notes: $\mathrm{N}_{\mathrm{a}}$ - pile side resistance; $\mathrm{N}_{\mathrm{y}}$ - pile creep point; $\mathrm{N}_{\mathrm{f}}-$ ultimate load; $\tau_{\mathrm{a}}-$ side resistance; $\sigma_{\mathrm{y}}-$ pile end resistance at creep point; $\sigma_{t}-$ pile end resistance at creep point.
The dependence of side frictions and pile end resistance on the number of piles is shown on Figures 5 and 6 .

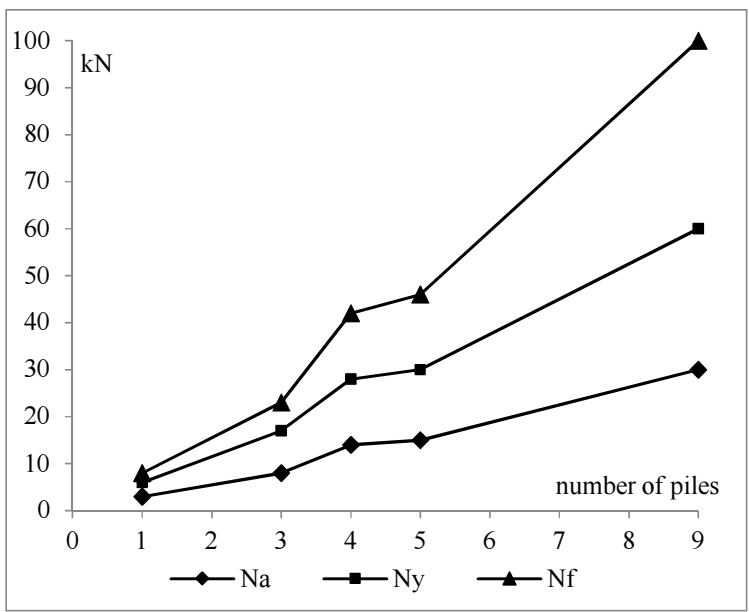

Fig. 5. The dependence of pile side resistance, pile creep point, pile failure load and the number of piles

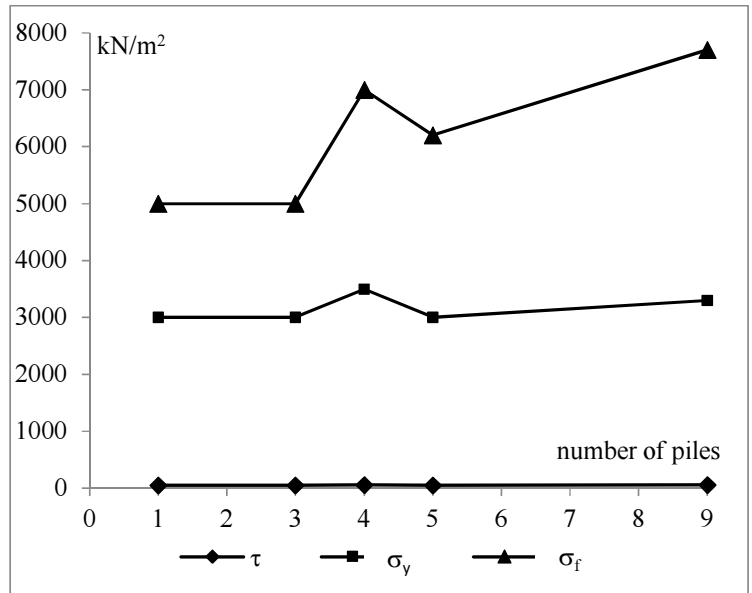

Fig. 6. The dependence of pile side resistance, pile creep point, pile failure load and the number of piles

The figures show that the side friction $\mathrm{Na}$ and creep point $\mathrm{Ny}$ do not depend too much on the number of piles, but it does have an effect on the ultimate load $\mathrm{Ny}$ that may be caused by the densening of sand during the driving of piles, but also the interplay of piles themselves. Method of characteristic points is described in early reseaches (Mets 1991, 1977).

To determine the influence of the raft, the raft plate was used without piles. The test results are shown on Figure 7. The creep point during the test is qy $=100 \mathrm{kN}$ and the ultimate load $q_{t}=140 \mathrm{kN}$ (pressure 625 and $875 \mathrm{kN} / \mathrm{m}^{2}$ ). 


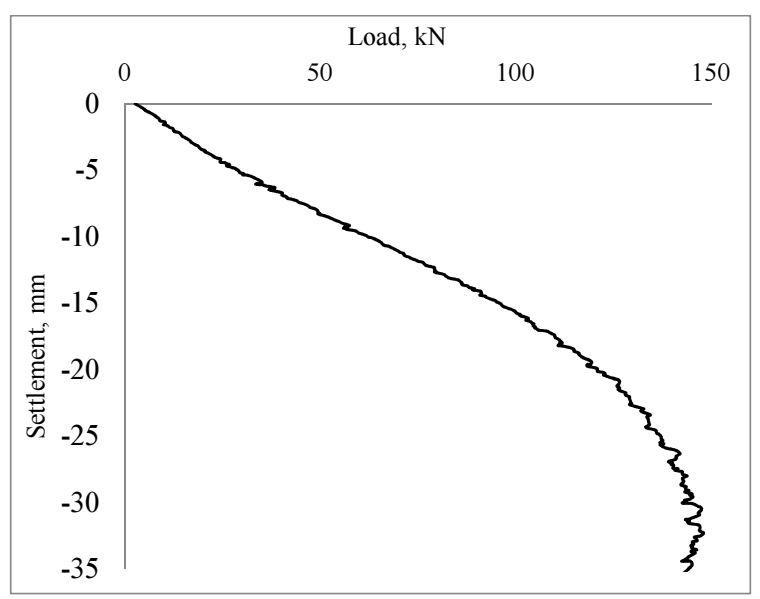

Fig. 7. The raft plate settlement curve

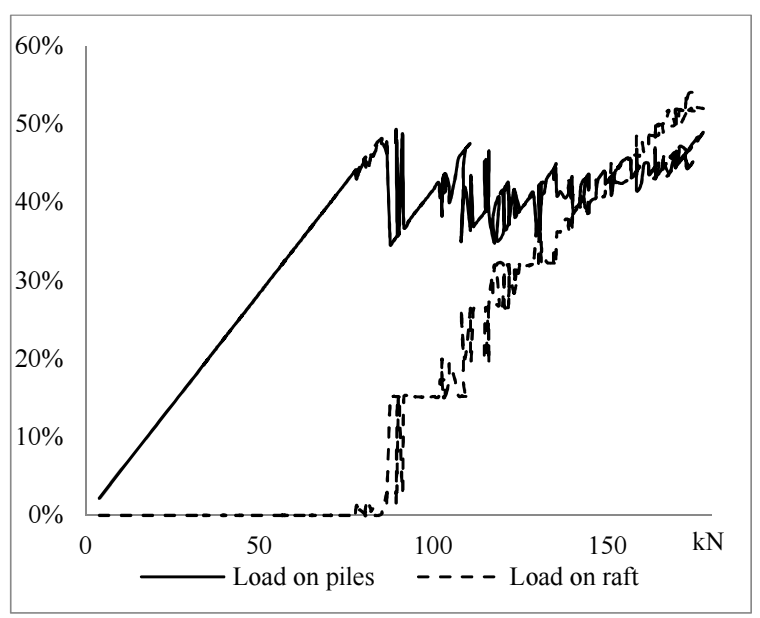

Fig. 8. Interaction of piles and plate

When the piles and the raft co-operate, the piles will be the first to start functioning and the load will be transferred to piles until the limit state is reached. In the limit state the plate will settle until it reaches the soil, creating the so-called thumbtack effect and plate starts working.

The Figure 8 shows the interaction between 4 piles and a plate. Up to $80 \mathrm{kN}$ - the ultimate load of piles only piles would work. After the plate would start working, the load on piles would decrease and reach the maximum only at the ultimate loads of the plate.

The graph showing the interaction between piles and plate lets us distinguish the creep point and the ultimate load. The dependence of $\mathrm{N}_{\mathrm{y}}$ and $\mathrm{N}_{\mathrm{f}}$ on the number of piles under the raft has been shown on Figure 9.

The figure shows that in the case of one and three piles the bearing capacity of piles should be lower than that of the plate. With four piles, the bearing capacity of the raft and piles equals the sum of the bearing capacity of separately tested plate and piles. It is even higher in the case of five or three piles.

The special resistance on the pile side, end and under the raft was determined during tests with 3,4 and 5 piles.

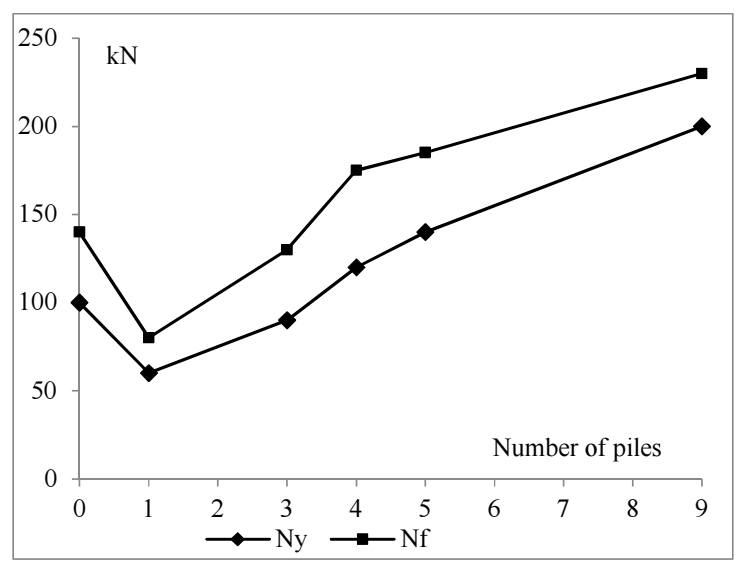

Fig. 9. Dependence of $\mathrm{N}_{\mathrm{y}}$ and $\mathrm{N}_{\mathrm{f}}$ on the number of piles

Table 3. Raft and pile resistances

\begin{tabular}{c|c|c|c}
\hline $\begin{array}{c}\text { Number of } \\
\text { piles }\end{array}$ & $\begin{array}{c}\text { Under the } \\
\text { plate } \\
\mathrm{kN} / \mathrm{m}^{2}\end{array}$ & $\begin{array}{c}\text { At pile end } \\
\mathrm{kN} / \mathrm{m}^{2}\end{array}$ & $\begin{array}{c}\text { Side re- } \\
\text { sistance } \\
\mathrm{kN} / \mathrm{m}^{2}\end{array}$ \\
\hline 3 & 540 & 8000 & 120 \\
\hline 4 & 575 & 12000 & 160 \\
\hline 5 & 625 & 9000 & 130 \\
\hline 0 & 875 & - & - \\
\hline
\end{tabular}

Table 3 shows that the load limit of the plate is lower with piles. On the other hand, the side resistance of piles increases 2.2-3 times and that of pile end, 2 times. This fact explains why the shear strength grows with the growing of normal pressure brought about by the plate.

\section{On site investigation}

The current research shows that for the raft and the piles to collaborate the piles need to work in a limit state. That will push the raft to work and assure the normal behaviour of pile base up till the creep point of the raft. In practice, these findings have been used for designing the solution for the foundations of the Lida beer factory (Mets, Leppik 2013).

The first serious solution was reached in 2010 in the construction process of the Lida Brewery. The project was designed on the bases of the pile end bearing capacity reaching $10000 \mathrm{kN} / \mathrm{m}^{2}$. Tests proved that the bearing capacity of the pile end would be $4000 \mathrm{kN} / \mathrm{m}^{2}$. As adding more piles would have complicated the whole process, it was decided to widen the grillage instead. Based on calculations, the expected settlement was $8 \mathrm{~cm}$. To monitor the situation, each pile was installed with a reaper and settlements were measured every week (see Fig. 10). 


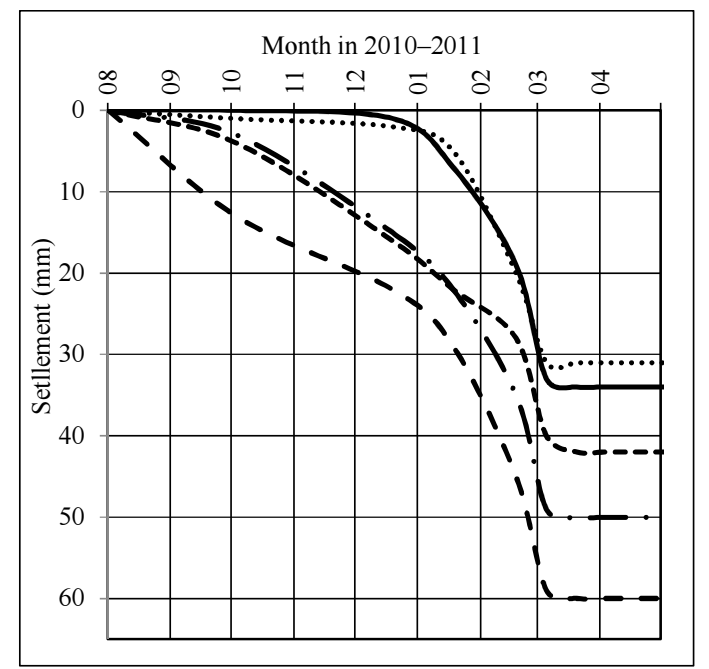

Fig. 10. Settlement of pileraft foundation on Lida Brewery

\section{Conclusions}

1. The interaction of piles and the raft enables a better use of pile bearing capacities and a decrease in the price of pile foundations.

2. For the interaction of piles and raft, the piles need to be loaded above the ultimate load. With the settling of the piles, a contact is created between the raft and the soil and a self-regulating system piles+raft will start working.

3. The test series indicated that the work of the system accords to our theoretical understanding of it, while various processes and phenomena that accompany it still require further research.

\section{References}

Kull, T. 2014. Vaialuse kandevõime: Master's thesis. Estonian University of Life Sciences (in Estonian).

Mets, M. 1977. Vaiade kandevõime, Ehitusgeoloogia kogumik $I V$. Tallinn: Valgus (in Estonian).

Mets, M. 1991. Iseloomulike punktide meetod, Ehitusgeoloogia kogumik $V$. Tallinn: Valgus (in Estonian).

Mets, M.; Leppik, V. 2013. Lida brewery pile foundation. Baltic piling. London: Taylor and Francis Group. http://dx.doi.org/10.1201/b15697 